\title{
Patterened Injuries- A Forensic Tool
}

\author{
Dr. Maninder Kaur, BDS, Tutor ${ }^{1}$, Dr. Jyoti Mago, MDS $^{2}$, \\ Dr. Amandeep Kaur, BDS ${ }^{3}$. Dr. Narayan Joshi, BDS ${ }^{4}$ \\ ${ }^{I}$ Deptt. of Oral Medicine and Maxillofacial Radiology, SKSS Dental College \& Hospital, Sarabha. \\ ${ }^{2,3,4}$ Senior Lecturer, Deptt. of Oral Medicine and Maxillofacial Radiology, \\ SKSS Dental College \& Hospital, Sarabha.
}

\begin{abstract}
Forensic dentistry is one of the most emerging specialties in dentistry. There are various measures which are source of information for the forensic dentists. These includes dental pulp, saliva, bite marks, rugoscopy, lip prints etc.. The current article deals with the patterned injuries as a forensic tool. It describes its classification, history, examination, collection of the records and its significance.
\end{abstract}

Keywords: bite marks, forensic odontology, patterned injury

\section{Introduction}

Forensic dentistry is defined by FDI as "Branch of dentistry which, in the interest of justice, deals with the proper handling and examination of dental evidence and with the proper evaluation and presentation of dental findings ".Bite marks are a result of "patterned injury" produced by human or animal dentitions and associated structures in any substance capable of being marked by these mean's. ${ }^{1}$ McDonald has defined bite mark as "a mark made by the teeth either alone or in combination with other mouth parts" During sexual attacks like rape, child sexual abuse, bite marks can be clustered around parts of body associated with sexuality. Bites can occur on the both victim and the suspect; teeth are used as weapon by aggressor and in self defense by the victim. ${ }^{2}$ Although, that are only a small portion of most forensic dentist's case load, bite marks represent the most challenging aspect of the discipline. In addition to the location of the bite mark, the type of severity of the injury may give investigators clues as to the mental state of the offender ${ }^{3}$. Other authors (Gall et al 2003) classify bite marks as examples of 'crush' injuries, where each tooth compresses the skin and soft tissues, crushing them. This action leaves indentations or breaks in the skin. ${ }^{4}$

\section{History}

Forensic Odontology came in existence in the early 1960's in the United States. It was not until the 1970's with the establishment of odontology section of the American Academy of Forensic Sciences when a more concerted effort to apply rigour was founded .In old English law, bite marks were recognized on paper "member proper for defense; included arms, legs and anterior teeth". In 1962,in the United States during the Salem Witch Trials, I Rev. Burroughs used to bite his victims. The judges readily accepted the bite mark as evidence and it was for the first time in United States that bite marks were used as evidence to solve a murder .In 1870, A.I. Robinson was suspected of murdering his mistress as evidence matching his teeth to a bite mark on victim's arm was presented. ${ }^{5}$ The bite mark evidence did not hold by 1890 it was recognized in the science field. ${ }^{6}$

\section{Classification}

Cutaneous bite marks- An injury in skin caused by contacting teeth (with or without the lips or tongue) which shows the representational pattern of the oral structures.

- Single bite

- Double bite- A bite within a bite

- Weave patterns of interposed clothing.

- Partial bite marks

- One arched(half bites)

I. One or few teeth

II. Unilateral (one sided marks due to incomplete dentition or uneven pressure)

- Indistinct or faded bite marks

I. Fused arch

II. Closed arch 
- Multiple bites.

Mac Donald's etiologic classification ${ }^{7}$ :

- Tooth pressure marks: tissue-direct application of pressure by teeth, example- incisal or occlusal surface.

- Tongue pressure marks: sufficient amount of tissue in mouth presses against rigid areas- lingual surfaces of teeth and palatal rugae, example-marks left on skin- suckling.

- Tooth scrape marks: scraping of teeth across bitten material, caused by any teeth, example-scratches, superficial abrasions

Webster's- foodstuff- theft/robbery ${ }^{8}$ :

Type I : food items fractures readily-limited tooth penetration. Example: hard chocolate.

Type II: considerable food penetration. Example: apple and other firm fruits.

Type III: complete penetration of food item with slide marks. Example- cheese.

\section{BITE MARKS ANALYSIS}

CLINICAL HISTORY: A history of bite or assault should be ascertained;

- When was the bite inflicted?

- Which part(s) of the body were bitten?

- Has the skin been washed since the assault?

- Which positions were the bitten parts at assault time?

EXAMINATION: As with all injuries, the wound should be described (areas of bruising, abrasions and lacerations etc.) and should preferably be sketched.

Photographs: photographs should be taken with and without scales, and preferably with bitten part being held in the same position as it was bitten

Most changes to morphology of a bite mark occur in the first 24 hours but indentations will be lost within hours, so the maximum amount of evidence to be gained from a bite mark must be secured as quickly as possible after the assault(Clark 1992 p.157) $)^{9}$

TRACE EVIDENC COLLECTION: forensic physician can supervise additional procedures such as swabbing the wound for DNA (buccal cells)/serological evidence, secretor status - ABO Antigens corresponding to the blood group are secreted by $76 \%$ of the population in their saliva.

Bite marks may also provide a source of assailant DNA - assessment of these injuries must therefore take place after collection of biological trace evidence, where relevant (Sweet et al 1997). ${ }^{10}$

EXAMINATION OF VICTIMS DENTITION: Odontologist will also supervise examination of the victims dentition (with or without taking of teeth impression) taking of bite marks impression ( for example with fast setting rubber or silicone based materials) for later comparison with suspects dentition.

Bite marks can be considered to be a spectrum of injuries ranging from a 'suction' mark, through marks indicating increasing violence ranging from bruising with no indentations to deep lacerations made by penetrating teeth (Knight 1996 and Clark 1992). ${ }^{11}$

Assessment of the probability of suspected persons dentition making the bite mark involves a subjective judgment and requires considerable experience and expertise.( Whittaker et al 1998) ${ }^{12}$

CRIMES INVOLVED IN BITE MARKS: Bite marks may be found on living or dead individuals where the person may be victim of the crime.

Bite marks may be produced during assault or abuse of children or adults which are frequently associated with sex related crimes and child abuse.

SIGNIFICANCE- It aids in individualization along that narrows down the investigation. It places the assailant with close proximity of the victim

Conclusion: Analysis of bite marks evidence has been assisting judiciary to answer crucial questions about interactions between people at crime scene. The shape of the bite mark can give useful clues about the person who caused it and may lead to the implication or exclusion of an individual under investigation. Physical bite mark evidence will always play an imperative part in criminal investigations. But currently, there is no agreement among forensic odontologist about the individuality (uniqueness) of the dentition and on the behavior of human skill during and after biting. With the slow but rational enhancement of techniques along scientific lines like the DNA analysis, bite mark evidence can reinforce and expand its sound and logical basis.

"Bite mark evidence has been used as an aid in the identification of the criminals in many instances. It is shown how perpetrators of violent injuries were detected from the bite marks on the victim or the perpetrators, on the food stuffs found at the scene of the crime, when the marks were compare to dental impressions taken subsequently." 
Some scientist recommends that thorough analysis of the size, position and other features of bite marks must be completed before any comparison with a suspect's dentition is made. It is possible to identify specific types of teeth by their class and characteristics.

Bite marks or patterned injuries are one of the most researched forensic tool in dentistry. Analyzing and comparing bite marks is basically made of two presumptions

- Any human dentition has characteristic shape, size and pattern and any individualistic features within the particular arch (could be a broken tooth or a developmental anomaly or even a simple mal-eruption)

- Skin records these features with greater resolution such that it is adequate to be used in the identification, inclusion or exclusion of a suspect as a perpetrator.

\section{REFERENCES}

[1]. Clark MA, Sandusky GE, Hawley DA, Pless JE, Fardal PM.et.al.(1991) Fatal and near fatal animal bite injuries. J Forensics Sci.36:1256-1261

[2]. Furness J (1981) A general review of bite mark evidence. Am J Forensic Med Pathol 2: 49-52.

[3]. Turvey EB(1999) Criminal Profiling: An introduction to behavioral Evidence Analysis. London: Academic Press.

[4]. Gall J.A.M., Boos S.C., Payne-James J.J., Culliford E.J. (2003), 'Forensic Medicine - Colour Guide', Churchill Livingstone.

[5]. Pierce LJ, Strickland DJ, Smith ES (1990) The case of Ohio vs Robinson: an 1870 bite mark case. Am J Forensic Med Pathol 11:171-177

[6]. Dorion RB (2004) Bite mark Evidence, New York: Marcel Dekker.

[7]. Macdonald DG, MacFarlane TW. (1972), 'Forensic odontology-Report of a case involving bite marks'. Glasg Dent J 3:16-19

[8]. Webster G (1982) A suggested classification of bite marks in food stuffs in forensic dental analysis. Forensic Sci. Int. 20:45-52.

[9]. Knight B. (1996), 'Forensic Pathology', 2nd Ed Arnold Publishers.

[10]. Clark D.H. (Ed) (1992), 'Practical Forensic Odontology', Butterworth Heinemann Ltd.

[11]. Sweet D, Lorente M, Lorente JA et al (1997), 'An improved method to recover saliva from human skin: the double swab technique', J Forensic Sci 42(2):320-2

[12]. Whittaker D.K., Brickley M.R., Evans L. (1998), 'A comparison of the ability of experts and non-experts to differentiate between adult and child human bite marks using receiver operating characteristics (ROC) analysis', Forensic Science International 92(1):11-20 